\title{
FORMATION OF NIOBIUM OXIDES BY ELECTROLYSIS FROM ACIDIC AQUEOUS SOLUTIONS ON GLASSY CARBON
}

\author{
Nataša M. Vukićević ${ }^{*}$, Vesna S. Cvetković ${ }^{1}$, Ljiljana S. Jovanović ${ }^{2}$ Miroslav M. Pavlovićc ${ }^{1}$, \\ Jovan N. Jovićević ${ }^{1}$ \\ ${ }^{1}$ Institute of Chemistry, Technology and Metallurgy, National Institute, Department of Electrochemistry, \\ University of Belgrade, Njegoševa 12, Serbia \\ ${ }^{2}$ Faculty of Science, Department of Chemistry, Biochemistry and Environmental Protection, \\ University of Novi Sad, Trg Dositeja Obradovića 3, Serbia \\ vukicevic@ihtm.bg.ac.rs
}

\begin{abstract}
In this study niobium oxide films were formed without peroxo-precursors from three different mixed acidic aqueous solutions on glassy carbon. Linear sweep voltammetry and potential step were techniques used for electrochemical experiments. The simultaneous and consecutive electrochemical reduction of water, nitrate and sulphate ions provided an alkaline environment with oxygen in the near vicinity of the working cathode, which in combination with the present niobium ions, produced niobium oxides and/or oxyhydroxides on the glassy carbon substrate. The formed deposits were analyzed using scanning electron microscopy and energy dispersive spectroscopy and appear to consist of $\mathrm{NbO}, \mathrm{NbO}_{2}$ and $\mathrm{Nb}_{2} \mathrm{O}_{5}$. Both the niobium and acid concentration of the electrolytes used influenced the morphology and particle size of the deposits. The formation of niobium-fluoride and hydrogen-niobiumoxide complexes is addressed.
\end{abstract}

Key words: electrochemical deposition; niobium oxides; acidic solution; glassy carbon

\section{ФОРМИРАЊЕ НА ФИЛМОВИ ОД ОКСИДИ НА НИОБИУМ СО ЕЛЕКТРОЛИЗА ОД КИСЕЛИ РАСТВОРИ НА СТАКЛЕСТА ГРАФИТНА ЕЛЕКТРОДА}

Во овој труд е изучувано формирањето на филмови на оксиди од ниобиум што се одвива без пероксидни медијатори од три различни водни раствори со различни рН вредности на стаклеста графитна електрода. Како експериментални техники во електрохемиските експерименти беа користени линеарна циклична волтаметрија и пулсни волтаметриски техники. Симултаната и последователната редукција на водата, како и на нитратните и сулфатните јони, доведува до локално зголемување на алкалноста и на концентрацијата на кислород во близина на работната електрода. При овие услови се формираат оксиди и оксихидриди на ниобиум на површината од работната електрода. Формираните филмови беа анализирани со употреба на скенирачка електронска микроскопија и енергетски дисперзивна спектроскопија, при што беше утврдено дека во составот на филмовите постојат оксиди на ниобиум од типот $\mathrm{NbO}, \mathrm{NbO}_{2}$ и $\mathrm{Nb}_{2} \mathrm{O}_{5}$. Морфологијата на депонираните честички и формираните филмови зависи од рН на водните раствори, како и од концентрацијата на јоните на ниобиум. Во рамките на овој труд вниманието е посветено и на формирањето на ниобиум флуорид и на хидроген комплекси на оксиди на ниобиум.

Клучни зборови: електрохемиска депозиција; оксиди на ниобиум; кисели водни раствори; стаклеста графитна електрода 


\section{INTRODUCTION}

Recently, niobium oxides have garnered increased attention due to their potential for industrial applications. The interest in niobium oxides is based on their excellent chemical stability and corrosion resistance in most acidic and basic media [1]. In addition, electrochromism, catalytic activity, good optical and dielectric properties, biocompatibility and high mechanical flexibility make these materials of great interest [1-3]. Some niobium oxide applications include solar cells and LEDs $[2,4,5]$, batteries and supercapacitors [2, 6, 7], catalysts $[4,8,9]$, electrochromic devices $[4,10]$, gas sensors [11] and biocompatible coatings for implants $[12,13]$. Niobium oxides appear in three stable forms: $\mathrm{NbO}, \mathrm{NbO}_{2}$ and $\mathrm{Nb}_{2} \mathrm{O}_{5}$. Each of these forms presents distinctive electric properties, ranging from conducting to insulating properties $[1,13$, 14]. Among them, niobium pentoxide $\left(\mathrm{Nb}_{2} \mathrm{O}_{5}\right)$, is often researched as the most thermodynamically stable oxide form. Additionally, niobium oxides have a complex crystalline morphology with an extensive number of polymorphic structures $[1,2]$. Besides, the method of niobium oxide synthesis has a great impact on thin oxide film structure and properties [1]. A number of methods have been utilized for formation of niobium oxides films. These methods include sol-gel $[4,15]$, anodic polarization [16], $\mathrm{dc}$ magnetron sputtering [13, 17], atomic layer deposition [18], chemical vapor deposition [19], thermal oxidation [20] and spray pyrolysis [10].

Alternatively, cathodic electrodeposition offers an opportunity for more accurate control of the metal oxide film microstructure composition, thickness and purity at potentially lower processing costs. In past decades, several metal oxides were efficiently deposited from aqueous solutions via electrodeposition [21-23]. An additional benefit of employing electrochemical deposition is the production of crystalline rather than amorphous metal oxide films $[24,25]$. In the available literature, there are only a few publications that address the topic of cathodic electrodeposition of niobium oxide films from acid solutions [22-24]. This is most likely due to difficulties characteristic to the processes of niobium and niobium oxide formation from aqueous systems. Primary reason for this is the very negative niobium reduction potential, which interferes with $\mathrm{H}_{2}$ evolution in aqueous electrolytes [26, 27]. There is also a predisposition of niobium to produce electrochemically inactive species when reacting with oxygen, often leading to the formation of stable clusters [24, 28]. Research conducted by McCullough et al. (1968) reported the mechanism of electroreduction of niobium $(\mathrm{V})$ in hydrochloric acid on a mercury electrode $[29,30]$. Thin films of niobium oxides have been obtained at more accessible electrodes $\left(\mathrm{SnO}_{2}\right.$-conducting electrode and platinum) from acidic aqueous solutions containing hydrogen peroxide as a precursor [22, 23] and by electrodeposition or combining sol gel procedures with electrodeposition [24].

This work is focused on the formation of niobium oxide thin films by electrochemical means on glassy carbon substrates. These films are formed from mixed acidic electrolytes without peroxo- or any other precursors, at room temperatures without electrolyte stirring. The influence of the potentials applied, niobium and acid concentrations in the electrolytes used on the deposit obtained are reported.

\section{EXPERIMENTAL}

Electrochemical experiments were performed in a custom made electrochemical cell (made of PTFE, Aldrich, USA), resistant to hydrofluoric acid (HF), supplied with argon atmosphere (Fig. 1). All experiments were performed at room temperature. Glassy carbon (GC, Sigma Aldrich, USA) embedded in epoxy resin (Struers, USA) was used as a working electrode, with a surface area of $0.13 \mathrm{~cm}^{2}$ that was exposed to the electrolyte. A niobium plate $(99.998 \%$, LTS Chemical Inc., USA) (surface area $=1.2 \mathrm{~cm}^{2}$ ) was used as a counter electrode. A saturated calomel electrode (SCE) inserted in a Luggin capillary was used as a reference electrode. All measured potentials are in reference to the SCE.

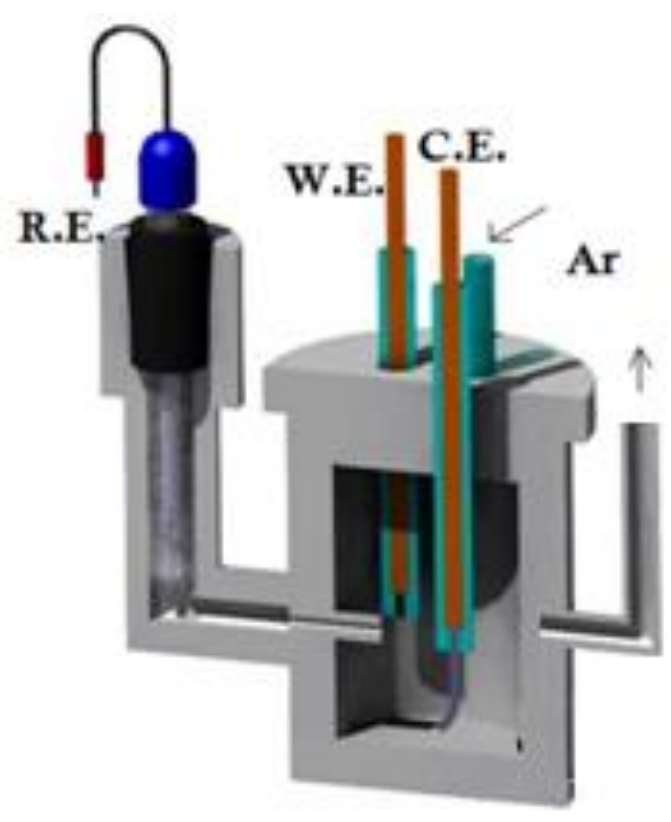

Fig. 1. Cross-section of the PTFE electrochemical cell 
Both the working and counter electrodes used were polished prior to experiments. The surface of the glassy carbon working electrode was mechanically polished with emery paper and then with a polishing cloth with $0.05 \mu \mathrm{m}$ grain size $\mathrm{Al}_{2} \mathrm{O}_{3}$ powder. Finally, the electrode was ultrasonically degreased in diluted $\mathrm{HCl}$ and rinsed in distilled and deionized water, respectively. Niobium electrode surfaces were mechanically polished by emery paper and then chemically polished in a mixture of cc. $\mathrm{HF}$ : cc. $\mathrm{HNO}_{3}=1: 1$ (p.a. Acros organics, USA and Merck, Germany, respectively) in three 10 second intervals, interrupted by rinsing in deionised water. The surfaces were finally washed with absolute ethanol (Zorka-Pharma, Šabac, Serbia).

Three different electrolytes were used to examine the electrochemical deposition and dissolution of niobium oxides. Niobium was introduced into the electrolytes by applying careful chemical dissolution of niobium metal in concentrated nitric (p.a. $\mathrm{HNO}_{3}$, Merck, Germany) and hydrofluoric acid (p.a. HF, Acros organic, USA) [28]. A concentrated acidic solution containing niobium ions was then diluted with distilled water (electrolyte C). Sulfuric (p.a. $\mathrm{H}_{2} \mathrm{SO}_{4}$, Ricca chemical, USA) acid was then added (electrolyte A and B). Electrolytes (referred to as $\mathrm{A}, \mathrm{B}$ and $\mathrm{C}$ in the text) were freshly prepared prior to each experiment; their compositions were as follows:

$$
\begin{aligned}
& \text { A. } 0.02 \mathrm{M} \mathrm{Nb}+0.7 \mathrm{M} \mathrm{HF}+0.4 \mathrm{M} \mathrm{HNO}_{3}+1 \mathrm{M} \mathrm{H}_{2} \mathrm{SO}_{4} ; \\
& \text { B. } 0.05 \mathrm{M} \mathrm{Nb}+0.7 \mathrm{M} \mathrm{HF}+0.4 \mathrm{MNO}_{3}+1 \mathrm{M} \mathrm{H}_{2} \mathrm{SO}_{4} ; \\
& \text { C. } 0.05 \mathrm{M} \mathrm{Nb}+0.7 \mathrm{M} \mathrm{HF}+0.4 \mathrm{MNO}_{3} \text {. }
\end{aligned}
$$

Both linear sweep voltammetry (LSV) and potential step techniques were conducted using EG\&G PAR 273A Potentiostat/Galvanostat controlled by Power Suite software (Princeton Applied Research, USA). In the LSV experiments, the potential was changed from a starting potential, $\mathrm{E}_{\mathrm{i}}$ (usually 50 to $100 \mathrm{mV}$ more negative than the reversible potential of the working electrode), to a final chosen negative (cathodic) potential, $\mathrm{E}_{\mathrm{f}}$, followed by the return scan with sweep rates between $5 \mathrm{mVs}^{-1}$ and $100 \mathrm{mVs}^{-1}$.

Quasi "open circuit" measurements included a potential pulse (duration of 5 minutes) at the negative cathodic potential end, $\mathrm{E}_{\mathrm{f}}$, whereupon the potentiostatic control was switched off and the system was left under a constant dissolution current (2 $\times 10^{-5} \mathrm{~A}$ ) until its return to the initial reversible potentials of the working electrode.

Deposits on the working electrode were obtained when the final chosen cathodic potential, $\mathrm{E}_{\mathrm{f}}$, was held constant for 6,60 and 180 minutes, at $\mathrm{T}=$ $25 \pm 0.5^{\circ} \mathrm{C}$. The working electrodes were then withdrawn from the cell under applied potential to maintain the deposited material. After electrodeposition, obtained deposit samples were washed with absolute ethanol and analyzed by scanning electron microscopy (SEM, JEOL, model JSM-5800, Japan) and energy dispersive spectroscopy (EDS, Oxford INCA 3.2, U.K.).

\section{RESULTS AND DISCUSSION}

The electrodeposition of niobium oxides from a number of aqueous solvent systems have been attempted by electrochemical $\mathrm{pH}$ manipulation of the solution [24]. These techniques rely on the electrochemical generation of $\mathrm{H}_{2}$ and $\mathrm{OH}^{-}$ions in aqueous solutions, which should promote niobium oxide films formation from acidic media.

In the acidic mixture of $\mathrm{HF}+\mathrm{HNO}_{3}+$ $\mathrm{H}_{2} \mathrm{SO}_{4}$, each of the aqueous solution constituent plays an important role: acids generally act as proton donors, $\mathrm{NO}_{3}{ }^{-}$from $\mathrm{HNO}_{3}$ oxidizes niobium, $\mathrm{HF}$ is an aggressive complexing agent that dissolves niobium oxides and niobium metal, and niobium fluoride complexes are a main source for the deposition of metallic niobium [22]. Finally, $\mathrm{SO}_{4}{ }^{2-}$ ions act as an additional complexing agent for niobium oxide species [28].

It was observed that the reversible potential of the glassy carbon (GC) working electrode moved to more negative values with increased niobium concentration; it decreased from $0.650 \mathrm{~V} v s$. SCE in solution A to $0.610 \mathrm{~V}$ vs. SCE in solution B. In solution $\mathrm{C}$, which does not contain $\mathrm{H}_{2} \mathrm{SO}_{4}$, $\mathrm{GC}$ reversible potential moved further to more negative values $(0.460 \mathrm{~V} v s$. SCE). This should be attributed to an increased concentration of active niobium ions that are not engaged in complexes made with sulphate anions [28]. A niobium anode was applied as a compensating source of niobium ions in the used solutions. No stirring was applied to the solution.

The voltammograms obtained with GC working electrode in used electrolytes (potential range from the $\mathrm{GC}$ reversible potential to $-1.000 \mathrm{~V}$ vs. SCE and back), are presented in Figure 2. In all solutions, two current waves $\left(\mathrm{I}_{\mathrm{C}}\right.$ and $\mathrm{II}_{\mathrm{C}}$ ) were observed in the cathodic part of the voltammograms when the cathodic end potential was $-0.600 \mathrm{~V} v s$. SCE, or more negative. In the anodic scan, the voltammograms displayed one or two oxidation current waves. 


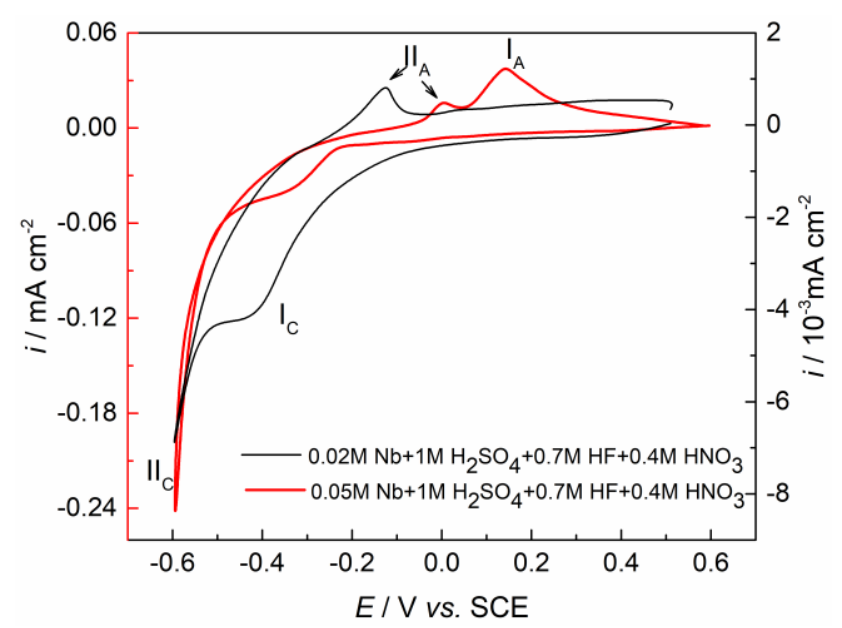

a)

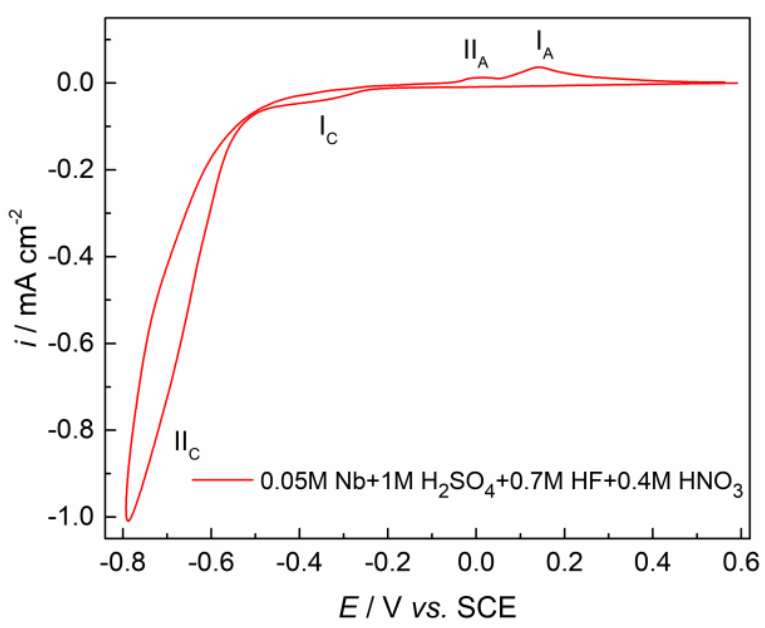

c)

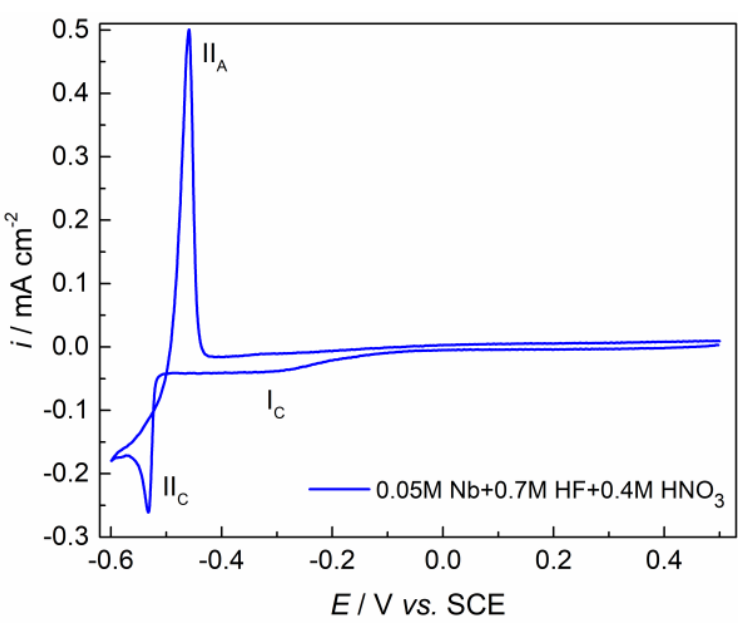

b)

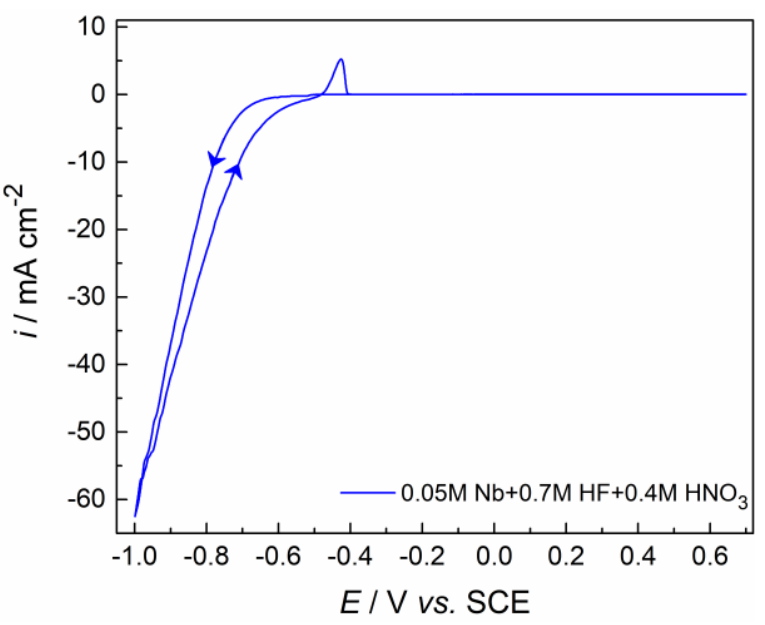

d)

Fig. 2. Cyclic voltammograms recorded in different electrolytes on the GC. Voltammograms were obtained with a scan rate $10 \mathrm{mV} / \mathrm{s}$, $\mathrm{T}=25^{\circ} \mathrm{C}$; cathodic end potential: a) and b) $-0.600 \mathrm{~V}$; c) $-0.800 \mathrm{~V}$; d) $-1.000 \mathrm{~V} v \mathrm{~s}$. SCE.

The first cathodic peak potential (wave $\mathrm{I}_{\mathrm{C}}$ around $-0.400 \mathrm{~V} v s$. SCE) and anodic peak (wave $\mathrm{II}_{\mathrm{A}}$ around $-0.070 \mathrm{~V} v s$. SCE) were shifted to positive potentials when the niobium concentration in the electrolyte used was increased (from $0.02 \mathrm{M}$ in Fig. 2a to $0.05 \mathrm{M}$ in Fig. 2c). In addition, in the more concentrated solutions, a second anodic current wave was observed (wave $\mathrm{I}_{\mathrm{A}}$, at around 0.170 V vs. SCE; Fig. 2a and 2c).

When the cathodic end potential became more negative than $-0.700 \mathrm{~V} v s$. SCE, a sharp rise in cathodic current density was accompanied by the formation of small gas bubbles, starting at around $-0.600 \mathrm{~V} v s$. SCE (Fig. 2d). This should be attributed to hydrogen evolution. The recorded values of the potential suggest high hydrogen evolution overpotential on the GC working electrode in the solutions used. To achieve an exponential increase of the hydrogen evolution current density, more negative values (up to $-1.000 \mathrm{~V} v s$. SCE) of overpotential were needed.

Cyclic voltammograms registered with the GC electrode in electrolyte B, with increasing holds at cathodic end potential are displayed in Figure $3 \mathrm{a}$. The prolonged holding at the potential of $-0.450 \mathrm{~V} v s$. SCE did not result in an increase in cathodic current, but it did generate an increase of the anodic currents and charge covered by the anodic peaks formed.

The voltammograms obtained on the GC electrode in electrolyte $\mathrm{C}$ with different sweep rates in the potential region explored (from 0.600 $\mathrm{V}$ to $-0.600 \mathrm{~V}$ ) are shown in Figure $3 \mathrm{~b}$. 


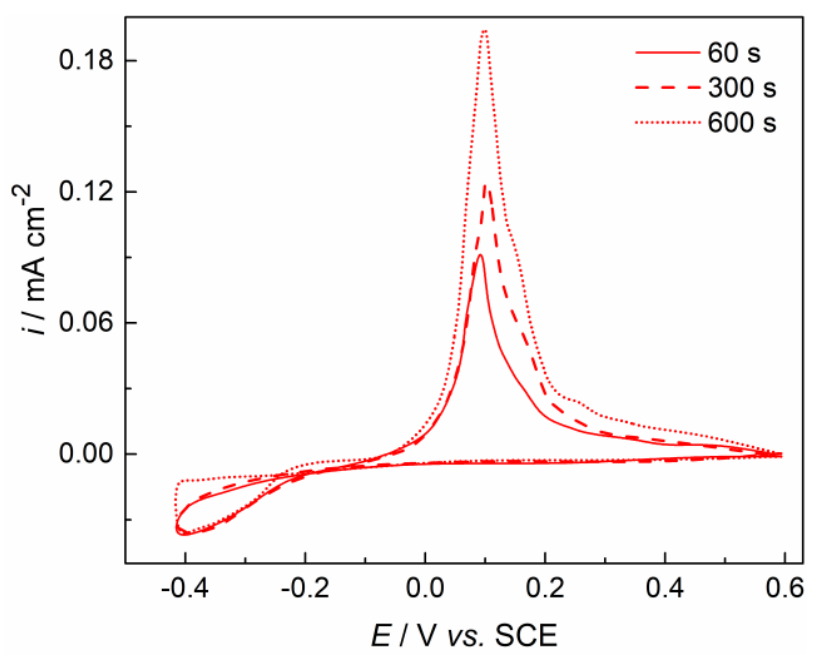

a)

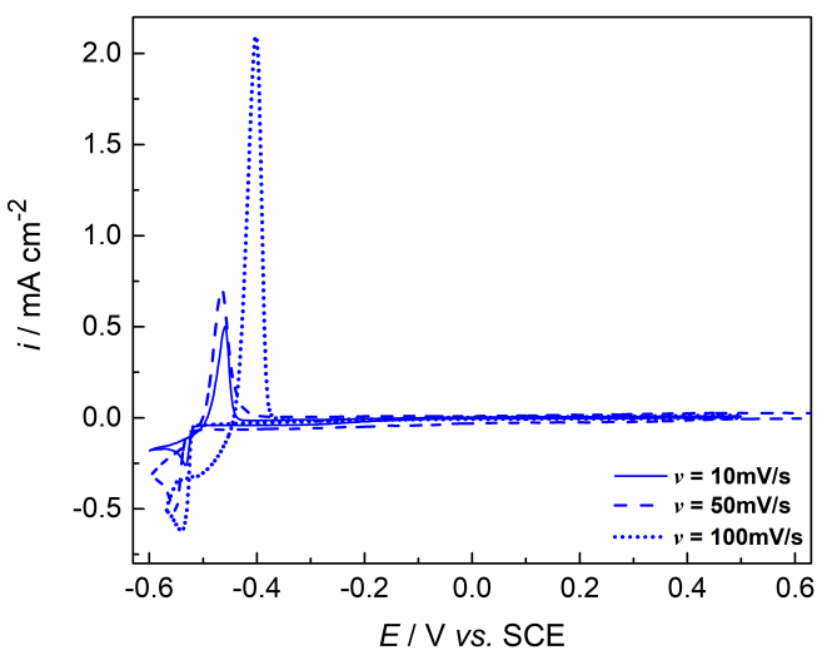

b)

Fig. 3. Cycling voltammograms of the $\mathrm{GC}$ electrode at $25^{\circ} \mathrm{C}$, in: a) electrolyte $\mathrm{B}$, cathodic potential end of $-0.450 \mathrm{~V} v \mathrm{~s}$. SCE obtained with increasing hold times, $\mathrm{v}=10 \mathrm{mV} / \mathrm{s}$, b) electrolyte $\mathrm{C}$, cathodic end potential of $-0.600 \mathrm{~V} v s$. SCE obtained with increasing sweep rates.

Potential-time diagrams recorded on the GC working electrodes obtained by "open circuit" measurements are given in Figure 4. The "open circuit" measurements resulted in the potential-time curves exhibiting plateaux at around $-0.100 \mathrm{~V}$ and $0.110 \mathrm{~V} v s$. SCE, respectively (Fig. 4). The number of plateaux and their potentials agree well with the number of anodic peaks that appear on the corresponding cyclic voltammogram (Fig. $2 \mathrm{a}$ and $2 \mathrm{c}$ ). This was pronounced in the case of electrolyte $\mathrm{B}$.

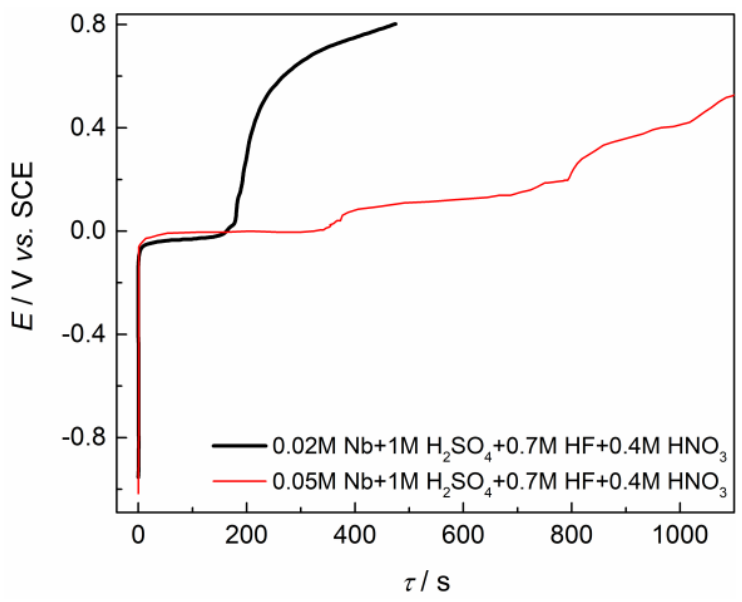

Fig. 4. "Open circuit" graphs obtained from the GC electrodes after potentiostatic deposition at $\mathrm{E}_{\mathrm{f}}=-1.000 \mathrm{~V} v \mathrm{~s}$. SCE for 5 minutes

SEM of the deposits formed at different potentials and from different electrolytes was con- ducted in order to gain information on the resulting morphology. Figures 5 and 6 show the surface appearance of the GC electrode after being held at an overpotential of $-0.400 \mathrm{~V} v s$. SCE from electrolyte $\mathrm{A}$ and electrolyte B, respectively. The deposit obtained at an overpotential of $-0.420 \mathrm{~V} v s$. SCE from electrolyte $\mathrm{C}$ is presented in Figure 7; the EDS analysis of this deposit is given in Figure 8.

In this study, XRD analyses were not utilized due to the amorphous nature of the GC substrate and the very thin layers of the deposits.

SEM photographs of niobium oxide/hydroxide obtained in $\mathrm{H}_{2} \mathrm{SO}_{4}$ electrolytes (Figs. 5 and 6), showed that the niobium concentration had an influence on the morphology of the deposits formed. It was found, that in $0.02 \mathrm{M}$ niobium electrolyte, the deposited oxide/hydroxide film consisted of agglomerates almost uniformly distributed over the entire electrode surface (Fig. 5a and b). With longer deposition time, a more compact layer with randomly distributed nodules was produced. Furthermore, there is a diverse surface morphology when the deposit was obtained from the electrolyte with higher niobium concentration $(0.05 \mathrm{M} \mathrm{Nb})$. A less homogeneous and partially crystalline layer on the electrode surface was recorded. Under these conditions, structures with a similar appearance to single crystal grains with regular edges could be seen. When removed from the solution, some of the deposits detached from the GC electrode due to poor adhesion. 


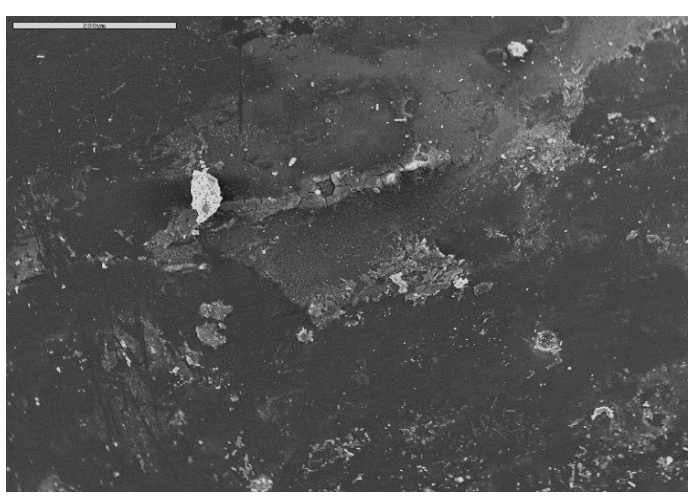

a)

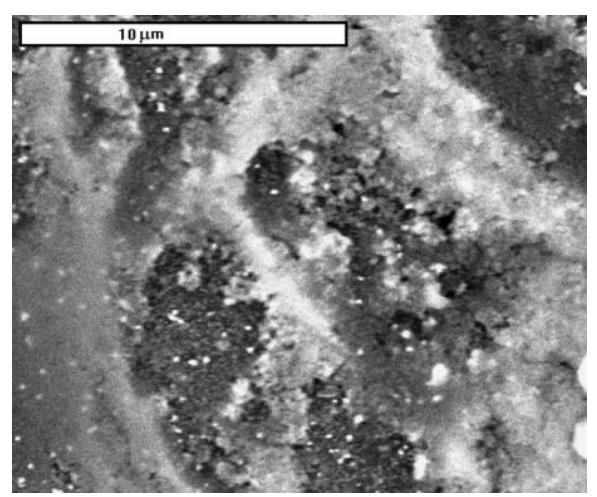

b)

Fig. 5. SEM images of the GC surface after being held in electrolyte $A$ at an overpotential of $-0.400 \mathrm{~V} v s$. SCE, for: a) 6 minutes and b) 60 minutes

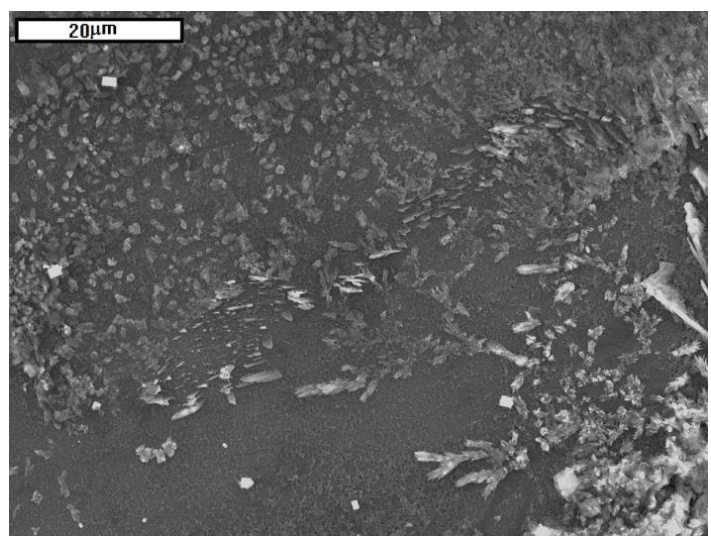

a)

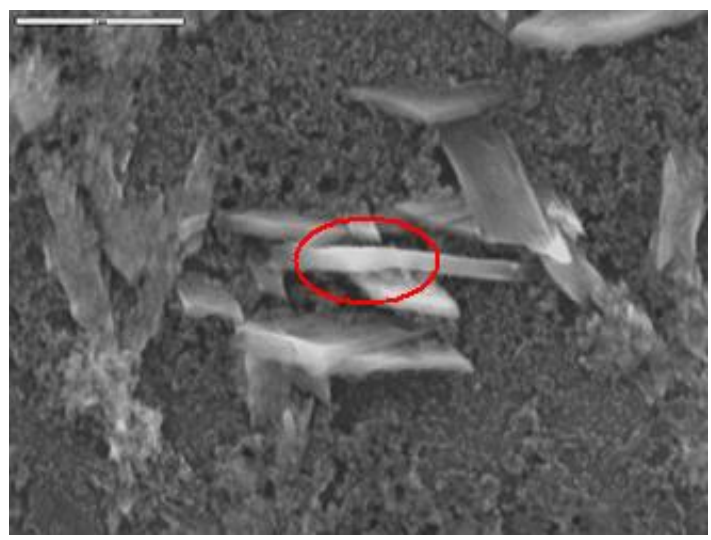

b)

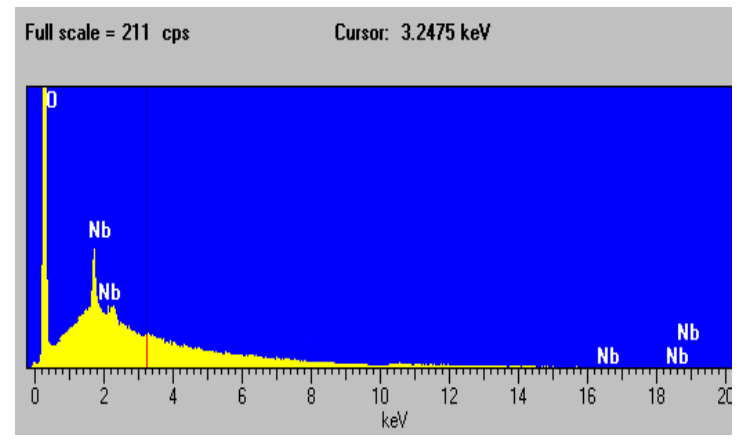

c)

Fig. 6. a) and b) SEM images at lower $(6000 \times)$ and higher $(15000 \times)$ magnification of the GC surface after being held for 60 minutes at potential $\mathrm{E}=-0.400 \mathrm{~V} v \mathrm{~s}$. SCE in electrolyte $\mathrm{B}, \mathbf{c}) \mathrm{EDS}$ analysis of the marked crystal from b).

An EDS analysis showed that only niobium and oxygen were detected as component elements of the deposits obtained on the GC working electrode by cathodic potentials applied from the solutions (Figs. 6c and 8). The thicker deposited layer produced in electrolyte $\mathrm{C}$ (Fig. 7), had a similar morphology as the layer obtained from electrolyte containing added $\mathrm{H}_{2} \mathrm{SO}_{4}$ and lower niobium concentration $(0.02 \mathrm{M} \mathrm{Nb})$. However, increased niobi- um concentration and deposition time resulted in the coalescence of deposited grains into larger agglomerates that were non-uniformly distributed over the electrode surface. Even though the deposit was compact and well adhered to the substrate, it exhibited cracking. These findings are in agreement with previous observations that the morphology of the deposited films depends on both HF concentration and deposition time [31, 32]. The 
results are also in accordance with previous studies that reported that a more negative the deposition potential leads to larger monocrystallites formed in the deposit [22]. The IR spectra of the deposits (niobium oxide products) obtained by cathodic deposition from an acid ( $\mathrm{pH}=2.5$ ) solution of niobium complexes showed that the more negative deposition potential leads to the formation of deposits with a higher content of water of crystallization and hydroxy groups [22]. The same authors claim that in the 300-200 $\mathrm{mV}$ vs. NHE region, only crystalline modifications of hexagonal and orthorhombic $\mathrm{Nb}(\mathrm{V})$ oxide were formed.

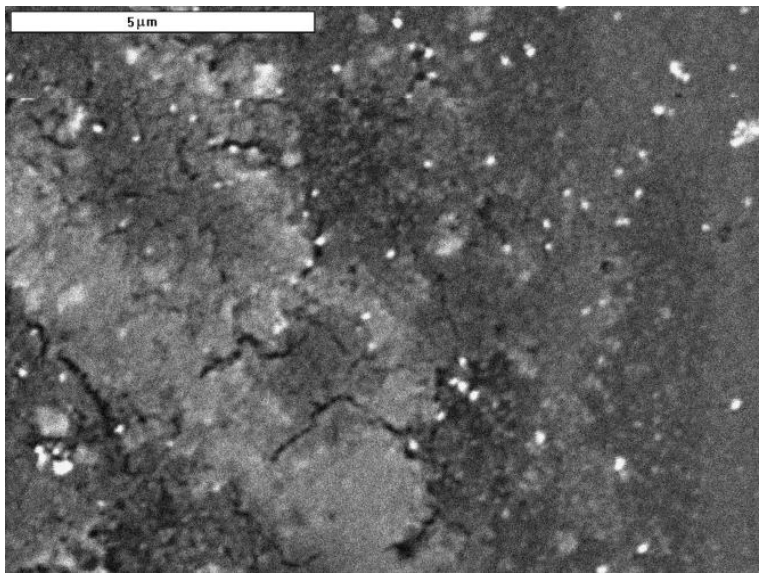

a)

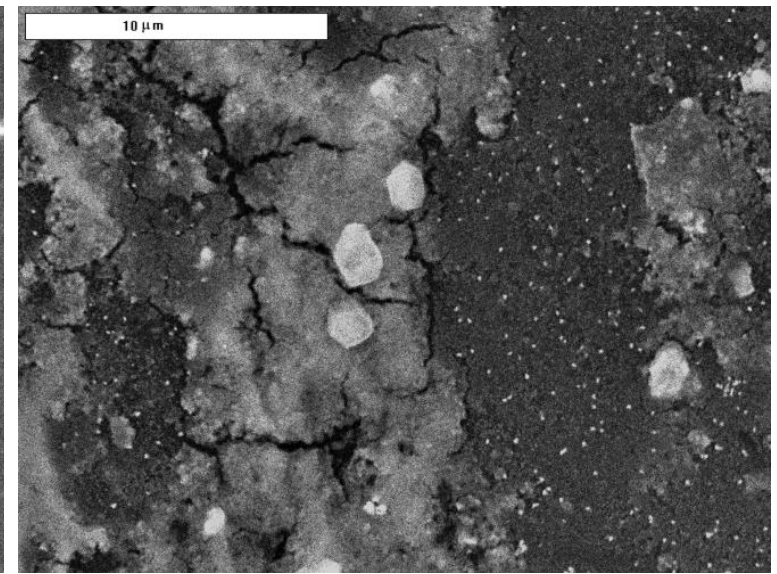

b)

Fig. 7. a) and b) SEM images at lower $(120 \times)$ and higher $(5000 \times)$ magnification of the GC surface after being held for 180 minutes at potential $\mathrm{E}=-0.420 \mathrm{~V} v \mathrm{~s}$. SCE in electrolyte $\mathrm{C}$

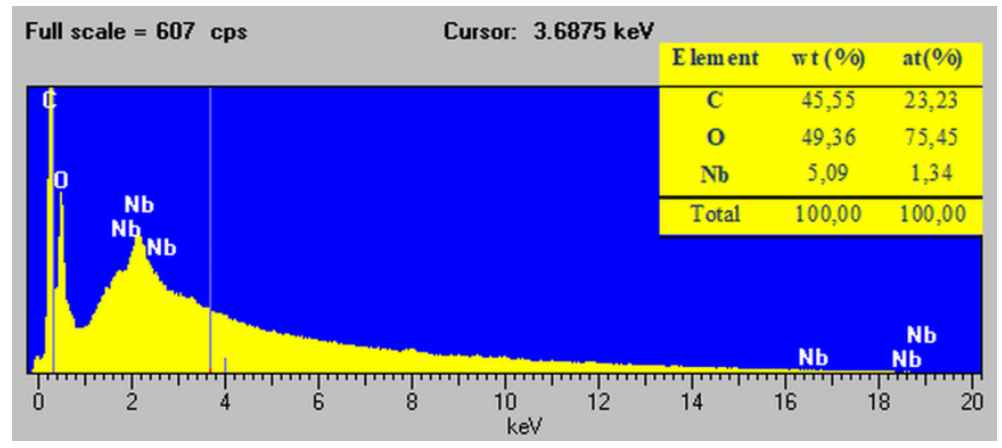

Fig. 8. EDS analysis of the sample from Figure 7

According to researchers in the field, water is an important reactant in the chemical behaviour of the niobium species. In the electrolytes containing $\mathrm{HNO}_{3}$ and $\mathrm{HF}$, dissolved niobium metal in an aqueous solution is in an oxidation state +5 and participates in an intermediate compound (niobium pentoxide; $\mathrm{Nb}_{2} \mathrm{O}_{5}$ ) [28]. In the presence of water, niobium pentoxide forms a different kind of niobic acid that could precipitate in the form of more or less hydrated gels $\left(\mathrm{Nb}_{2} \mathrm{O}_{5} \times \mathrm{nH}_{2} \mathrm{O}\right)$. The mechanism of $\mathrm{Nb}_{2} \mathrm{O}_{5}$ dissolution in a mixture of $\mathrm{HF}$ and $\mathrm{H}_{2} \mathrm{SO}_{4}$ depends on the $\mathrm{HF}$ concentration and follows a second order reaction [32]. At the same time, depending on the concentration of $\mathrm{HF}$ acid in the solution $(\approx 1 \mathrm{M})$, any formed $\mathrm{Nb}_{2} \mathrm{O}_{5}$ can be quickly transformed into a fluoride or oxofluoride acidic species, with a general formula of $\left[\mathrm{NbO}_{\mathrm{x}-}\right.$ $\left.\mathrm{F}_{\mathrm{y}}, \mathrm{H}_{2} \mathrm{O}\right]^{5-2 \mathrm{x}-\mathrm{y}}$ [28]. Moreover, different kinds of niobium fluoride species can react with nitric acid; products of this reaction might be trinitratoxoniobium(V) and nitrylfluoride [28].

The chemistry of niobium species in aqueous solutions is very complex, making it difficult to identify the mechanism for niobium electrodeposition processes [23, 24]. Some studies have shown that the presence of HF in the electrolyte plays an important role in niobium deposition and its growth process [32]. This corrosive/dissolution agent in the electrolyte attacks niobium species or niobium oxide leaching niobium precursor ionic 
species to the solution. Regarding the present experimental conditions (where $\mathrm{pH} \approx 1$ and $0.7 \mathrm{M}$ $\mathrm{HF})$, the tendency of $\mathrm{Nb}(\mathrm{V})$ to be complexed by fluorides, resulting $\mathrm{NbF}_{6}^{-}$complex could be expected, which afterwards can be reduced to a metallic niobium [29, 30, 32]. Besides, in a HF-based electrolyte, in the near location of the working electrode oxygen $\left(\mathrm{O}^{2-}\right)$ species are generated which are needed for different kinds of niobium oxides $\mathrm{NbO}, \mathrm{NbO}_{2}, \mathrm{Nb}_{2} \mathrm{O}_{5}$ and $\mathrm{NbO}_{4}^{-}$formation [32].

These results imply that our deposit was formed by cathodic and anodic reactions and most probably includes niobium oxides and oxihydroxides. The Pourbaix diagram for the niobium-water system supports the assumption, because in the domain limited by the potentials and $\mathrm{pH}$ used in our experiments, different kinds of niobium oxides $\left(\mathrm{NbO}, \mathrm{NbO}_{2}, \mathrm{Nb}_{2} \mathrm{O}_{5}, \mathrm{NbO}_{4}^{-}\right)$species and even traces of niobium could be expected [26].

In the literature, there is a long list of cathodic and anodic reactions that can take part in individual acidic niobium sulphate, nitrate and fluoride solutions. Therefore, there is no reason why any of these solutions should be excluded as a possible source of niobium oxide formation during our experiments. There is only one report of GC being used as the working electrode but in different acid mixtures of an aqueous niobium solution [24]. The mechanism of hydrolysis and oxide formation of cationic peroxocomplexes of niobium by the electrogenerated base $\left(\mathrm{OH}^{-}\right)$and oxide species $\left(\mathrm{O}^{2-}\right)$ near the cathode are results of preceding reactions $[23,33,34]$ :

$$
\begin{gathered}
2 \mathrm{H}_{2} \mathrm{O}+2 \mathrm{e}^{-} \leftrightarrow \mathrm{H}_{2}+2 \mathrm{OH}^{-} \\
\mathrm{NO}_{3}{ }^{-}+\mathrm{H}_{2} \mathrm{O}+2 \mathrm{e}^{-} \leftrightarrow \mathrm{NO}_{2}{ }^{-}+2 \mathrm{OH}^{-} \\
\mathrm{O}_{2}+2 \mathrm{H}_{2} \mathrm{O}+4 \mathrm{e}^{-} \leftrightarrow 4 \mathrm{OH}^{-} \\
\mathrm{NO}_{3}{ }^{-}+2 \mathrm{e}^{-} \leftrightarrow \mathrm{NO}_{2}{ }^{-}+\mathrm{O}^{2-} \\
2 \mathrm{NO}_{3}{ }^{-}+2 \mathrm{e}^{-} \leftrightarrow 2 \mathrm{NO}_{2}{ }^{-}+\mathrm{O}_{2}{ }^{2-} \\
\mathrm{NO}_{3}{ }^{-}+\mathrm{e}^{-} \leftrightarrow \mathrm{NO}_{2}+\mathrm{O}^{2-}
\end{gathered}
$$

The presence of cathodic peaks in voltammograms, in acidic electrolytes used, at the potential range from $-0.350 \mathrm{~V}$ to $-0.430 \mathrm{~V} v s$. SCE, by some authors is attributed to the niobium(V) reduction from a $\mathrm{NbF}_{6}{ }^{-}$complex to lower oxidation state [24]. Additionally, the reaction between the ionic niobium species generated by the reduction of the $\mathrm{NbF}_{6}$ complex and the products of the electro catalytic oxygen reduction most probably results in the formation of a different kind of niobium oxide on the working electrode.

In some reports, films that consist of more or less stable oxides, such as $\mathrm{NbO}, \mathrm{NbO}_{2}$ and $\mathrm{Nb}_{2} \mathrm{O}_{5}$
[35] were observed on the surface of the working electrode in the potential region of $1.200 \mathrm{~V}$ to $1.000 \mathrm{~V} v s$. NHE in acidic solutions. At cathodic potentials around $-1.000 \mathrm{~V} v s$. NHE, hydrogen ions diffuse from the electrolyte to the oxide film, probably forming a chemical bond with the oxygen of $\mathrm{Nb}_{2} \mathrm{O}_{5}$ in the oxide films, made previously under the anodic potential or with naturally present oxygen [35]:

$$
\mathrm{Nb}_{2} \mathrm{O}_{5}+\mathrm{xH}^{+}+\mathrm{xe}^{-} \leftrightarrow \mathrm{H}_{\mathrm{x}} \mathrm{Nb}_{2} \mathrm{O}_{5}
$$

At negative potentials, starting from $0.000 \mathrm{~V}$ $v s$. NHE, polycrystalline hydroxide species prevail and the films deposited from the electrolyte, based on niobium complexes in the potential interval from 0.300 to $-0.500 \mathrm{~V} v s$. NHE, were made of $\mathrm{Nb}(\mathrm{V})$ oxides [22]. Some authors reported the presence of a cathodic peak at potentials negative to $-0.500 \mathrm{~V} v s$. NHE after anodization, which may be related to the incorporation of $\mathrm{H}^{+}$ions into the amorphous oxide. The penetration of the hydrogen into the niobium oxide during the cathodic polarization leads to the formation of bronzes of type $\mathrm{H}_{\mathrm{x}} \mathrm{Nb}_{\mathrm{x}}{ }^{(4+)} \mathrm{Nb}_{2-\mathrm{x}}{ }^{(5+)} \mathrm{O}_{5}$. The recorded anodic oxidation peaks (waves $\mathrm{I}_{\mathrm{A}}$ and $\mathrm{II}_{\mathrm{A}}$; Fig. 2) were primarily due to the reversible dissolution of a different kind of niobium oxide complex that is formed during the reign of reduction potentials [22].

The first anodic peak (wave $\mathrm{II}_{\mathrm{A}}$ in this case) should correspond to the formation of $\mathrm{NbO}$ and is in good agreement with the Pourbaix diagram [26]. The second anodic peak should correspond to the oxidation of $\mathrm{H}_{x} \mathrm{Nb}_{2} \mathrm{O}_{5}$ to $\mathrm{Nb}_{2} \mathrm{O}_{5}$ (the reverse of reaction 7). A number of authors agree that this reaction, along with $\mathrm{NbO}$ and $\mathrm{Nb}_{2} \mathrm{O}_{5}$ formation, were recorded only with cathodic pre-treatment in the form of a linear sweep from positive to negative potentials as a part of a full voltammograms cyclic $[22,35]$.

\section{CONCLUSIONS}

The formation of niobium oxides was performed on the glassy carbon working electrode without oxidizing precursors and stirring in aqueous solutions of three acid mixtures.

There were almost simultaneous and consecutive electrochemical reductions of water, nitrate and sulphate ions during the reduction part of the linear sweep cycle. Furthermore, the potentiostatic regime (in the potential region from 0.600 $\mathrm{V}$ to $-1.000 \mathrm{~V} v s$. SCE), provided an alkaline environment and oxygen in the near vicinity of the working cathode, which with the niobium ions 
produce niobium oxides and/or oxyhydroxides on the glassy carbon. The deposits appeared on the working electrode in the form of thin films, which according to EDS analysis seemed to be made only of niobium and oxygen (most probably as $\mathrm{NbO}$, $\mathrm{NbO}_{2}$ and $\mathrm{Nb}_{2} \mathrm{O}_{5}$ ). Both, crystalline and amorphous deposits obtained were similar in composition and appearance to those reported in the literature as a result of the deposition from very acidic aqueous solutions, yet with oxidizing precursors on different working electrode substrates and electrolyte stirring.

The deposit changed from a non-crystalline to a partially crystalline layer with a number of grains in the form of single crystals, when niobium concentration in the electrolyte increased from $0.02 \mathrm{M}$ to $0.05 \mathrm{M} \mathrm{Nb}$.

Acknowledgements. This work was supported by the Ministry of Education, Science and Technological Development of the Republic of Serbia (Grant No. 172060).

\section{REFERENCES}

[1] C. Nico, T. Monteiro, M. P. F. Graça, Niobium oxides and niobates physical properties: Review and prospects, Prog. Mater. Sci. 80, 1-37 (2016). DOI:10.1016/j.pmatsci.2016.02.001.

[2] R. A. Rani, A. S. Zoolfakar, A. P. O’Mullane, M. W. Austin, K. Kalantar-Zadeh, Thin films and nanostructures of niobium pentoxide: Fundamental properties, synthesis methods and applications, J. Mater. Chem. A. 2, 15683-15703 (2014). DOI:10.1039/c4ta02561j.

[3] E. T. Salim, J. A. Saimon, M. K. Abood, M. A. Fakhri, Some physical properties of $\mathrm{Nb}_{2} \mathrm{O}_{5}$ thin films prepared using nobic acid based colloidal suspension at room temperature, Mater. Res. Express. 4, 106407 (2017). DOI:10.1088/2053-1591/aa90a6.

[4] M. A. Aegerter, Sol-gel niobium pentoxide: A promising material for electrochromic coatings, batteries, nanocrystalline solar cells and catalysis, Sol. Energy Mater. Sol. Cells. 68, 401-422 (2001). DOI:10.1016/S0927-0248(00)00372-X.

[5] B. Y. Jeong, E. H. Jung, Micro-mountain and nanoforest pancake structure of $\mathrm{Nb}_{2} \mathrm{O}_{5}$ with surface nanowires for dye-sensitized solar cells, Met. Mater. Int. 19, 617-622 (2013). DOI:10.1007/s12540-013-3035-5.

[6] M. T. Brumbach, T. M. Alam, R. H. Nilson, P. G. Kotula, B. B. McKenzie, R. G. Tissot, B. C. Bunker, Ruthenium oxide-niobium hydroxide composites for pseudocapacitor electrodes, Mater. Chem. Phys. 124, 359-370 (2010).

DOI:10.1016/j.matchemphys.2010.06.047.

[7] G. Park, N. Gunawardhana, C. Lee, S. M. Lee, Y. S. Lee, M. Yoshio, Development of a novel and safer energy storage system using a graphite cathode and $\mathrm{Nb}_{2} \mathrm{O}_{5}$ anode, J. Power Sources. 236, 145-150 (2013). DOI:10.1016/j.jpowsour.2012.10.102.
[8] A. de S. Santos, L. Gorton, L. T. Kubota, Nile blue adsorbed onto silica gel modified with niobium oxide for electrocatalytic oxidation of NADH, Electrochim. Acta. 47, 3351-3360 (2002). DOI:10.1016/S0013-4686(02)00272-4.

[9] A. Bonakdarpour, R. T. Tucker, M. D. Fleischauer, N. A. Beckers, M. J. Brett, D. P. Wilkinson, Nanopillar niobium oxides as support structures for oxygen reduction electrocatalysts, Electrochim. Acta. 85, 492500 (2012). DOI:10.1016/j.electacta.2012.08.005.

[10] S. H. Mujawar, A. I. Inamdar, C. A. Betty, V. Ganesan, P.S. Patil, Effect of post annealing treatment on electrochromic properties of spray deposited niobium oxide thin films, Electrochim. Acta. 52, 4899-4906 (2007). DOI:10.1016/j.electacta.2007.01.054.

[11] R. A. Rani, A. S. Zoolfakar, J. Z. Oua, M. R. Field, M. Austin, K. Kalantar-Zadeh, Nanoporous $\mathrm{Nb}_{2} \mathrm{O}_{5}$ hydrogen gas sensor, Sensors Actuators, B Chem. 176, 149-156 (2013). DOI:10.1016/j.snb.2012.09.028.

[12] E. Eisenbarth, D. Velten, J. Breme, Biomimetic implant coatings, Biomol. Eng. 24, 27-32 (2007). DOI:10.1016/j.bioeng.2006.05.016.

[13] G. Ramírez, S. E. Rodil, S. Muhl, D. Turcio-Ortega, J. J. Olaya, M. Rivera, E. Camps, L. Escobar-Alarcón, Amorphous niobium oxide thin films, J. Non. Cryst. Solids. 356, 2714-2721 (2010).

DOI:10.1016/j.jnoncrysol.2010.09.073.

[14] M. J. Olszta, E. C. Dickey, Interface stoichiometry and structure in anodic niobium pentoxide, Microsc. Microanal. 14, 451-458 (2008). DOI:10.1017/S1431927608080756.

[15] M. Maček, B. Orel, Electrochromism of sol-gel derived niobium oxide films, Sol. Energy Mater. Sol. Cells. 54, 121-130 (1998). DOI:10.1016/S0927-0248(98)00062-2.

[16] S. Cattarin, M. Musiani, B. Tribollet, Nb electrodissolution in acid fluoride medium, $J$. Electrochem. Soc. 149, B457-B464 (2002). DOI:10.1149/1.1502690.

[17] N. Sangwaranatee, M. Horprathum, J. Kaewkhao, Deposition of transparent niobium oxide thin film by DC reactive magnetron sputtering, Key Eng. Mater. 675676, 217-220 (2016).

DOI:10.4028/www.scientific.net/KEM.675-676.217.

[18] J. I. Eastcott, A. Parakh, M. T. Y. Paul, A. W. H. Lee, M. W. Bilton, B. D. Gates, Nanoscale thin films of niobium oxide on platinum surfaces: creating a platform for optimizing material composition and electrochemical stability, Can. J. Chem. 96, 260-266 (2018). DOI:10.1139/cjc-2017-0595.

[19] S. A. O’Neill, I. P. Parkin, R. J. H. Clark, A. Mills, N. Elliott, Atmospheric pressure chemical vapour deposition of thin films of $\mathrm{Nb}_{2} \mathrm{O}_{5}$ on glass, J. Mater. Chem. 13, 2952-2956 (2003). DOI:10.1039/b307768n.

[20] J. H. Lim, J. Choi, Formation of niobium oxide nanowires by thermal oxidation, J. Ind. Eng. Chem. 15, 860-864 (2009). DOI:10.1016/j.jiec.2009.09.013.

[21] S. Karuppuchamy, Cathodic electrodeposition of oxide semiconductor thin films and their application to dyesensitized solar cells, Solid State Ionics. 151, 19-27 (2002). DOI:10.1016/S0167-2738(02)00599-4. 
[22] S. S. Fomanyuk, Y. S. Krasnov, G. Y. Kolbasov, V. N. Zaichenko, Electrochemical deposition of electrochromic niobium oxide films from an acidic solution of niobium peroxo complexes, Russ. J. Appl. Chem. 86, 644-647 (2013). DOI:10.1134/S1070427213050054.

[23] I. Zhitomirsky, Electrolytic deposition of niobium oxide films, Mater. Lett. 35, 188-193 (1998). DOI:10.1016/S0167-577X(97)00248-6.

[24] G. R. Lee, J. A. Crayston, Studies on the electrochemical deposition of niobium oxide, J. Mater. Chem. 6, 187-192 (1996). DOI: 10.1039/JM9960600187.

[25] K. I. Popov, S. S. Djokić, N. D. Nikolić, V. D. Jović, Morphology of Electrochemically and Chemically Deposited Metals, Springer International Publishing, Cham, 2016. DOI:10.1007/978-3-319-26073-0.

[26] E. Asselin, T. M. Ahmed, A. Alfantazi, Corrosion of niobium in sulphuric and hydrochloric acid solutions at 75 and $95{ }^{\circ} \mathrm{C}$, Corros. Sci. 49, 694-710 (2007). DOI:10.1016/j.corsci.2006.05.028.

[27] CRC Handbook of Chemistry and Physics, CRC Press, Inc, Boca Raton, 2002.

[28] A. Aspart, C. Z. Antoine, Study of the chemical behavior of hydrofluoric, nitric and sulfuric acids mixtures applied to niobium polishing, Appl. Surf. Sci. 227, 17-29 (2004). DOI:10.1016/j.apsusc.2003.10.001.

[29] J. G. McCullought, L. Meites, The electroreduction of niobium $(\mathrm{V})$ in hydrochlorid acid solutions at mercury electrodes, II. Controlled-potential coulometry and stirred-pool chronoamperometry, Electroanal. Chem. Interfacial Electrochem. 19, 111-123 (1968).

[30] J. G. McCullough, L. Meites, The electroreduction of niobium(V) in hydrochloric acid solutions at mercury electrodes, I. Polarography and chronopotentiometry, Electroanal. Chem. Interfacial Electrochem. 18, 123135 (1968).

[31] I. Sieber, H. Hildebrand, A. Friedrich, P. Schmuki, Formation of self-organized niobium porous oxide on niobium, Electrochem. Commun. 7, 97-100 (2005). DOI:10.1016/j.elecom.2004.11.012.

[32] C. D. Rodrigues, N. R. de Tacconi, W. Chanmanee, K. Rajeshwar, Cathodic electrosynthesis of niobium oxide one-dimensional nanostructures with tailored dimensions, Electrochem. Solid State Lett. 13, B69-B72 (2010). DOI:10.1016/S0005-1098(98)00152-6.

[33] D. A. Tkalenko, Makrokinetika katodnykh protsessov $v$ gidroksidnykh i nitratnykh rasplavakh, Naukova Dumka, Kiev, 1993.

[34] D. A. Tkalenko, Elektrokhimiya nitratnykh rasplavov, Naukova Dumka, Kiev, 1983.

[35] I. Arsova, L. Arsov, N. Hebestreit, A. Anders, W. Plieth, Electrochemical formation of anodic oxide films on $\mathrm{Nb}$ surfaces: Ellipsometric and Raman spectroscopical studies, J. Solid State Electrochem. 11, 209-214 (2007). DOI:10.1007/s10008-005-0089-4.

[36] A. G. Muñoz, G. Staikov, Electrodeposition of metals on anodized thin $\mathrm{Nb}$ films, J. Solid State Electrochem. 10, 329-336 (2006). DOI:10.1007/s10008-005-0090-y. 